Council were informed that the Scottish Division had received an invitation to give evidence before the Guillebaud Committee, when it was sitting in Scotland, and a draft memorandum prepared by this Division was considered and approved.

Notice was taken that the provisional committee on the Mackintosh report had been adjourned sine die.

\title{
PAPERS
}

"The Biological Background of Human Behaviour."

Speakers: Dr. John Bowlby, Dr. Robert Hinde, Dr. Michael Chance.

\author{
APPENDIX \\ Diploma in Psychological Medicine \\ 20th List of Training Schools-approved in categories shown on 18 February, 1954.
Psychiatric Institutions other than Burnley General Hospital Psychiatric Depart- Mental Hospitals and Mental ment (for six months of two-year period in \\ Deficiency Hospitals $\quad$. $\quad$. $\quad$ approved psychiatric institutions). \\ Adult Out-Patients' Clinic . . . . The Victoria Hospital, Burnley (affiliated to \\ Burnley General Hospital).
}

\section{NOTICES BY THE HON. LIBRARIAN}

The Library is open to members between the hours of 9 a.m. and 5 p.m., Saturdays, 9 a.m. and 12 noon. Books are issued to borrowers during these hours.

The Hon. Librarian will endeavour to obtain, as far as possible, any books on psychiatry and allied subjects required by members.

\section{Library Lending Department Regulations}

1. Books shall be lent only to members within the United Kingdom and Eire who are not in arrears with their subscriptions.

2. No member may borrow from the Library more than three volumes at one time.

3. Books and journals are sent carriage paid from the Library, but members are responsible for the books from the time they leave the Library until they are received back.

4. Books damaged or lost while in possession of a member will be repaired at his expense or must be replaced by him.

5. A member borrowing a book or periodical from the Library shall be required to sign and return to the Librarian a form of receipt for the same, which will be regarded as an acceptance of these Regulations.

6. A member shall be entitled to retain a book or periodical borrowed from the Library for a period of twenty-eight days, unless the book is required by another member, in which case it can be recalled by the Librarian at the expiration of fourteen days.

7. In the event of a member failing to return any book or periodical within seven days after receiving notice from the Librarian (on the expiration of the period referred to in Rule 6), the Library Committee shall be at liberty to purchase another copy, the cost to be charged to such member, who shall not be allowed to borrow another book until the sum thus expended shall have been paid.

8. All communications should be addressed to "The Librarian, Royal MedicoPsychological Association, 11 Chandos Street, Cavendish Square, W.1." 


\section{Circulation of Journals}

The following journals are available at the Library:

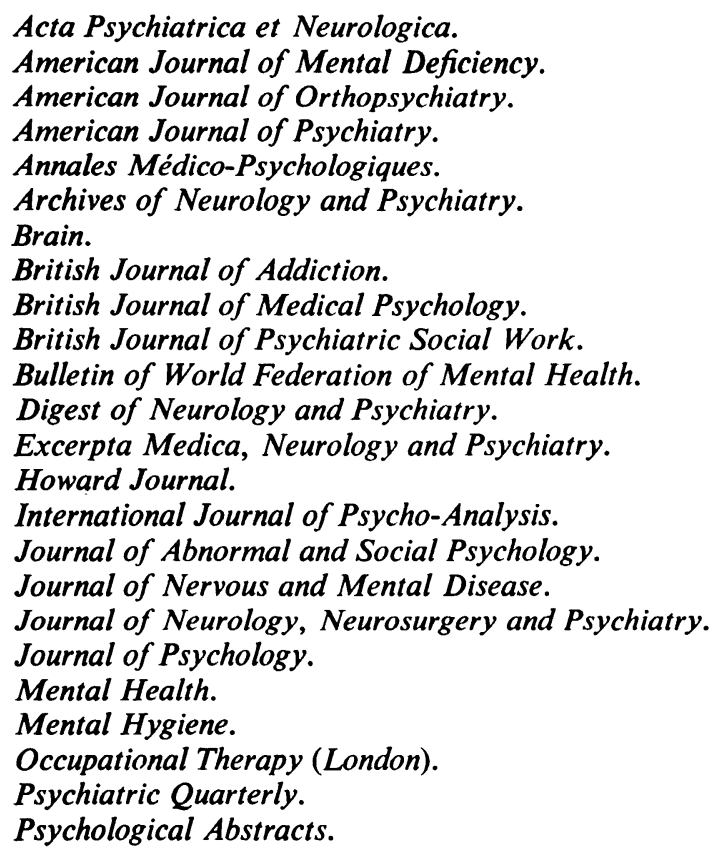

\section{NOTICES BY THE REGISTRAR}

\section{The Diploma in Psychological Medicine}

The examination for the Association's Diploma in Psychological Medicine will be held annually in May and November. The examination comprises:

Part I

(a) Psychology.

(b) Anatomy and Physiology in their relation to nervous and mental diseases.

Part II (a) Psychiatry.

(b) Psychosomatic Medicine and Neurology.

Fees are eight guineas for Part I and twelve guineas for Part II, and are payable to the Registrar, R.M.P.A.

Prospective candidates should apply to the Registrar at least two months before the examination at which they wish to sit.

Full particulars may be obtained from the Registrar, R.M.P.A., 11 Chandos Street, London, W.1, on receipt of stamped, addressed envelope.

\section{THE ASSOCIATION'S MEDALS AND PRIZES, 1954}

Attention is specially drawn to the Medals and Prizes which are offered annually by the Association: The conditions of award are set out fully in the Year-Book. 